\title{
SGK1-Dependent Upregulation of Connective Tissue Growth Factor by Angiotensin II
}

\author{
Azeemudeen Hussain $^{a} \quad$ Amanda W. Wyatt ${ }^{a}$ Kan Wang ${ }^{a}$ Madhuri Bhandaru ${ }^{a}$ \\ Raja Biswas $^{a}$ Diana Avram ${ }^{a}$ b Michael Föller ${ }^{a}$ Rexhep Rexhepaja \\ Björn Friedrich $^{b}$ Susanne Ullrich ${ }^{a, b}$ Gerhard Müller ${ }^{c}$ Dietmar Kuhl $^{d}$ \\ Teut Risler $^{b} \quad$ Florian Lang $^{\mathrm{a}}$ \\ Departments of a Physiology and ${ }^{b}$ Internal Medicine IV, University of Tübingen, Tübingen, ${ }^{c}$ Department of \\ Nephrology and Rheumatology, University of Göttingen, Göttingen, and d Department of Biology, Chemistry, \\ and Pharmacy, Free University Berlin, Berlin, Germany
}

\section{Key Words}

Fibrosis - Serum- and glucocorticoid-inducible kinase • Human kidney fibroblasts · Connective tissue growth factor

\begin{abstract}
Angiotensin II has previously been shown to trigger fibrosis, an effect involving connective tissue growth factor (CTGF). The signaling pathways linking angiotensin II to CTGF formation are, however, incompletely understood. A gene highly expressed in fibrosing tissue is the serum- and glucocorticoid-inducible kinase SGK1. The present study explored whether SGK1 is transcriptionally regulated by angiotensin $\mathrm{II}$ and participates in the angiotensin II-dependent regulation of CTGF expression. To this end, experiments have been performed in human kidney fibroblasts and mouse lung fibroblasts from gene-targeted mice lacking SGK1 $\left(\mathrm{sgk}^{-/}\right)$ and their wild-type littermates $\left(\mathrm{sgk}^{+/+}\right)$. In human renal fibroblasts, SGK1 and CTGF protein expression were enhanced by angiotensin II (10 $\mathrm{nM}$ ) within $4 \mathrm{~h}$. In sgk ${ }^{+/+}$mouse fibroblasts, SGK1 transcript levels were significantly increased after $4 \mathrm{~h}$ of angiotensin II treatment. Angiotensin II stimulated both transcript and protein abundance of CTGF in fibroblasts from $\mathrm{sgk}^{+/+}$mice, effects significantly blunted in fi-
\end{abstract}

broblasts of $\mathrm{sgk}^{-/-}$mice. In conclusion, angiotensin II stimulates the expression of SGK1, which is in turn required for the stimulating effect of angiotensin II on the expression of CTGF. Thus, SGK1 presumably contributes to the profibrotic effect of angiotensin II.

Copyright $\odot 2008$ S. Karger AG, Basel

\section{Introduction}

The pleotropic actions of angiotensin II include the stimulation of matrix protein formation and deposition leading to fibrosis in a variety of tissues including heart $[1,2]$, vascular tissue [3-6], kidney [7-13], liver [14, 15], lung [16] and retina [17]. The effect of angiotensin II is mediated by upregulation of connective tissue growth factor (CTGF) [15, 18-27]. Moreover, angiotensin II and CTGF have been shown to mediate the mitogenic effect of advanced glycation end products [28].

A candidate kinase linking the angiotensin receptors with CTGF expression is the serum- and glucocorticoidinducible kinase SGK1 [29], a kinase originally cloned as

This work was supported by grants from DFG and BMBF (D.K., F.L.).

\section{KARGER}

Fax +4161306 1234 E-Mail karger@karger.ch www.karger.com
(ㄷ) 2008 S. Karger AG, Basel

$1420-4096 / 08 / 0312-0080 \$ 24.50 / 0$

Accessible online at: www.karger.com/kbr
Florian Lang

Department of Physiology, University of Tübingen

Gmelinstrasse 5, DE-72076 Tübingen (Germany)

Tel. +4970712972 194, Fax +497071295618

E-Mail florian.lang@uni-tuebingen.de 
a glucocorticoid-inducible gene [30] and subsequently shown to be strongly upregulated by a variety of triggers $[31,32]$ including mineralocorticoids $[33,34]$. SGK1 is expressed in a variety of fibrosing tissues such as those affected by diabetic nephropathy [35-37], glomerulonephritis [38], cardiac fibrosis [39], lung fibrosis [40], liver cirrhosis [41], Crohn's disease [42], and fibrosing pancreatitis [43].

The present study aimed to elucidate the possible participation of SGK1 in the stimulation of CTGF expression by angiotensin II.

\section{Materials and Methods}

\section{Preparation of Fibroblasts}

Human fibroblast cell lines derived from normal kidney (TK 173) were cultured as described previously [44, 45]. Briefly, the cells were cultivated in culture flasks at $37^{\circ} \mathrm{C}$ in $5 \% \mathrm{CO}_{2}$ atmosphere in DMEM, containing $5.6 \mathrm{mM}$ glucose supplemented with $10 \%$ fetal calf serum, $20 \mathrm{mM}$ L-glutamine and $100 \mathrm{U} / \mathrm{ml}$ penicillin/100 mg/ml streptomycin and passaged every week.

To determine the role of SGK1 in angiotensin II-induced CTGF expression, fibroblasts were collected from SGK1 knockout mice $\left(s g k 1^{-/-}\right)$and their wild-type littermates $\left(s g k 1^{+/+}\right)$[46]. Several fibroblast preparations have been used. The yield required for Western blotting was achieved with lung fibroblasts. To harvest primary lung fibroblasts from $\mathrm{sgk} 1^{-/-}$and $\mathrm{sgk} 1^{+/+}$mice, whole lungs were removed under anesthesia from 8- to 14-week-old animals and transferred to $90-\mathrm{mm}$ cell culture dishes containing $2 \mathrm{ml}$ of DMEM supplemented with $10 \%$ fetal calf serum, $100 \mathrm{U} / \mathrm{ml}$ penicillin, $100 \mathrm{mg} / \mathrm{ml}$ streptomycin and $2 \mathrm{~mm} \mathrm{~L}$-glutamine (Gibco-Invitrogen, Karlsruhe, Germany). The tissue was cut into small pieces and cultured under standard cell culture conditions $\left(37^{\circ} \mathrm{C}, 5 \% \mathrm{CO}_{2}\right)$. Cell growth was observed $2-4$ days after initial plating. Fibroblasts were identified by positive staining for fibronectin and used in experiments between passages 2 and 6 . Animal experiments were conducted according to the guidelines of the German Animal Welfare Law and were approved by local authorities.

\section{Western Blotting}

For Western blotting, human renal fibroblasts or $s g k 1^{+/+}$and $s g k 1^{-/-}$mouse lung fibroblasts were grown in 60-mm culture dishes for $32 \mathrm{~h}$. Serum was removed for $18 \mathrm{~h}$ and cells were thereafter treated with angiotensin II, $10 \mathrm{nM}$, for $4 \mathrm{~h}$. After treatment, cells were lysed and whole cell lysates $(50 \mu \mathrm{g})$ were subjected to $10 \%$ SDS-PAGE in $10 \%$ Tris-glycine buffer. The proteins were transferred to nitrocellulose membranes and the membrane incubated for $1 \mathrm{~h}$ in PBS containing 5\% fat-free milk and $0.1 \%$ Tween (blocking buffer) to block unspecific binding sites. The membranes were incubated overnight at $4^{\circ} \mathrm{C}$ with a goat polyclonal CTGF primary antibody (from Santa Cruz, Heidelberg, Germany, diluted 1:400 in blocking buffer, or from R\&D Systems, Wiesbaden, Germany, at a concentration of $0.1 \mu \mathrm{g} / \mathrm{ml}$ ) or with a rabbit polyclonal SGK1 primary antibody (from Upstate Biotechnology, Dundee, UK, diluted 1:1,000, or from Pineda, Berlin, Germany, 1:100). The CTGF antibody from R\&D Systems recognizes two isoforms of about 36 and $40 \mathrm{kDa}$. The 36-kDa band was chosen for analysis. After incubation with HRP-conjugated anti-goat or anti-rabbit secondary antibodies (Santa Cruz) for CTGF and SGK1, respectively, proteins binding the antibodies were visualized with enhanced chemiluminescence according to the manufacture's instructions (Amersham, Freiburg, Germany). Membranes were probed with GAPDH antibody (Santa Cruz) to control loaded and transferred amounts of protein. Densitometric analysis of CTGF protein bands was performed using Scion Image (Scion, Frederick, Md., USA). The specific bands were referred to the staining of GAPDH or of non-specific bands. Due to differences of the exposure times of different Western blots, the densities of the bands were normalized to the values of the respective non-treated controls or wildtypes.

Quantification of $m$ RNA by Real-Time RT/PCR

For real-time PCR total RNA was isolated from cultured fibroblasts of $s g k 1^{+/+}$and $s g k 1^{-/-}$mice using the Qiagen RNeasy Fibrous Tissue Midi Kit (Qiagen, Hilden, Germany). SGK1 or CTGF mRNA were transcribed using Taq polymerase (Roche Diagnostics GmbH, Mannheim, Germany) and quantified by PCR using a light cycler system (Roche Diagnostics GmbH, Roche Applied Science, Mannheim, Germany). For the detection of mouse CTGF mRNA the specific primers used were: sense: $5^{\prime}$-ACG ACG CCA AGG ACC GCA-3'; antisense: 5'-TTG TAA TGG CAG GCA CAG-3'. For detection of SGK1 transcript levels the specific primers used were: sense: $5^{\prime}$-TGTCTTGGGGCTGTCCTGTATG-3'; antisense: 5'-GCTTCTGCTGCTTCCTTCACAC-3'. The transcript levels of the housekeeping gene GAPDH were also determined for each sample using a commercial primer kit (Search LC, Heidelberg, Germany). Amplification of the target DNA was performed during 35 cycles, each $10 \mathrm{~s}$ at $95^{\circ} \mathrm{C}, 10 \mathrm{~s}$ at $68^{\circ} \mathrm{C}$ and $16 \mathrm{~s}$ at $72^{\circ} \mathrm{C}$. Melting curve analysis confirmed the specificity of amplified products, which were then separated on $1.5 \%$ agarose gels to verify the size of the PCR product. Results were calculated as a ratio of the target vs. housekeeping gene transcripts.

Statistical Analysis

Data are provided as means \pm SEM, $n$ represents the number of independent experiments. All data were tested for significance using ANOVA or t-test, as appropriate, and only results with $\mathrm{p}<$ 0.05 were considered statistically significant.

\section{Results}

\section{SGK1 and CTGF Expression Is Stimulated by} Angiotensin II in a Fibroblast Cell Line

To explore whether the serum- and glucocorticoid-inducible kinase SGK1 is a transcriptional target of angiotensin II in human tissues, experiments were performed with fibroblast cell lines derived from normal kidneys. As illustrated in figure 1, after exposure to angiotensin II (10 $\mathrm{nM}$ ) for $4 \mathrm{~h}$ the SGK1 protein abundance was significantly increased in the fibroblasts. Next, the expression of CTGF was analyzed (fig. 2). Incubation of the cells with 
Fig. 1. Angiotensin II (AII) stimulates SGK1 expression in human fibroblasts. a Representative Western blot demonstrating SGK1 protein abundance after a 4-hour incubation in the absence or presence of $10 \mathrm{nM}$ AII. A non-specific band served as loading control. b Arithmetic means $\pm \operatorname{SEM}(n=6)$ of SGK1 over GAPDH protein abundance or normalized to a non-specific band in fibroblasts from normal human kidneys after a 4-hour incubation in the absence (left bar) or presence (right bar) of $10 \mathrm{nM}$ AII. * Significant $(\mathrm{p}<0.05)$ difference from control.

Fig. 2. Angiotensin II (AII) increases CTGF protein expression in human fibroblasts. a Representative Western blot demonstrating CTGF and GAPDH protein levels in human renal fibroblasts after a 4hour treatment with $10 \mathrm{nM}$ AII. b Arithmetic means \pm SEM $(n=6-7)$ of CTGF over GAPDH protein abundance or normalized to a non-specific band in fibroblasts from normal human kidney fibroblasts after a 4-hour incubation in the absence (left bar) and presence (right bar) of 10 nM AII. * Significant $(p<0.05)$ difference between AII and control.
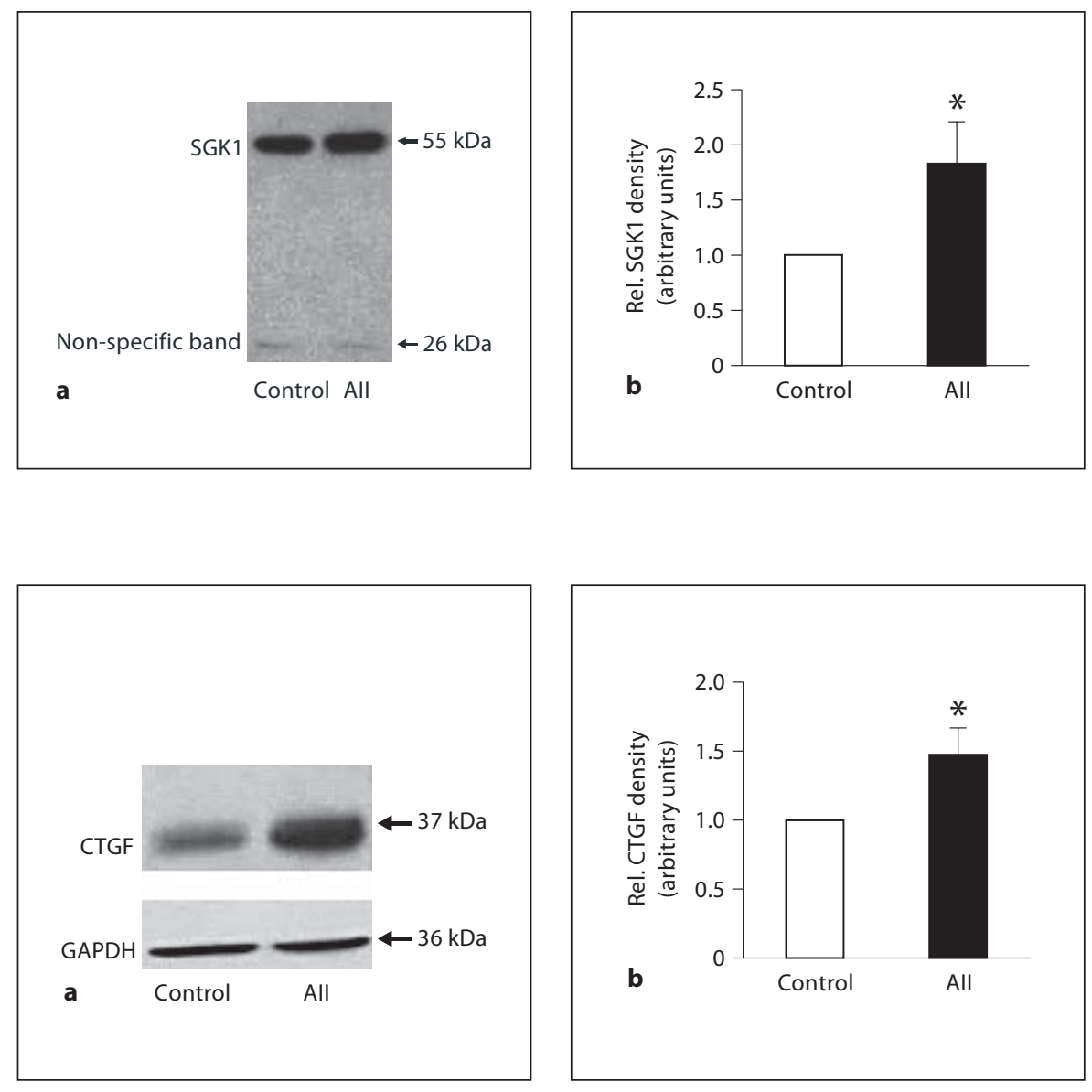

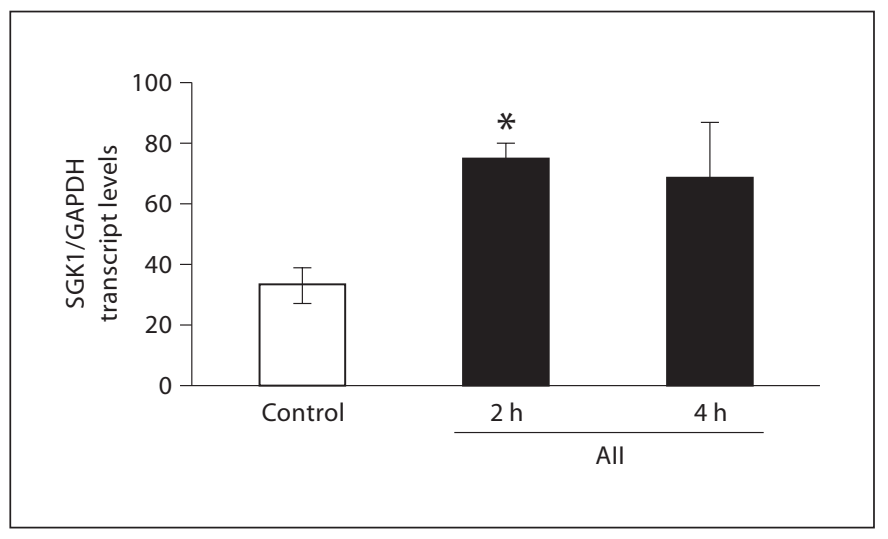

Fig. 3. Angiotensin II (AII) increases SGK1 transcript levels in lung fibroblast from wild-type mice. Arithmetic means \pm SEM $(n=3)$ of SGK1 transcript levels in relation to GAPDH transcript levels of the same preparations of primary mouse lung fibroblasts prior to and after 2 - and 4-hour treatment with $10 \mathrm{nM} \mathrm{AII.} \mathrm{*} \mathrm{Sig-}$ nificant difference from control. angiotensin II for $4 \mathrm{~h}$ significantly increased the expression of CTGF. These observations indicate that angiotensin II upregulates the expression of SGK1 and CTGF.

\section{Angiotensin II Increased the Expression of SGK1 in \\ Primary Mouse Fibroblasts}

To test whether SGK1 is functionally relevant for the stimulation of CTGF expression by angiotensin II, experiments have been performed in lung fibroblasts from SGK1 knockout mice $\left(s g k 1^{--}\right)$and their wild-type littermates $\left(s g k 1^{+/+}\right)$. First, the effect of angiotensin II on SGK1 expression was analyzed in lung fibroblasts from wildtype mice. After exposure of primary lung fibroblasts to angiotensin II (10 nM), SGK1 mRNA was significantly increased within a 2-hour treatment (fig. 3).

CTGF Expression Is Not Stimulated by Angiotensin II in the Absence of SGK1

CTGF transcript levels were then analyzed in primary lung fibroblasts from both wild-type and sgk $1^{-/-}$mice. As 


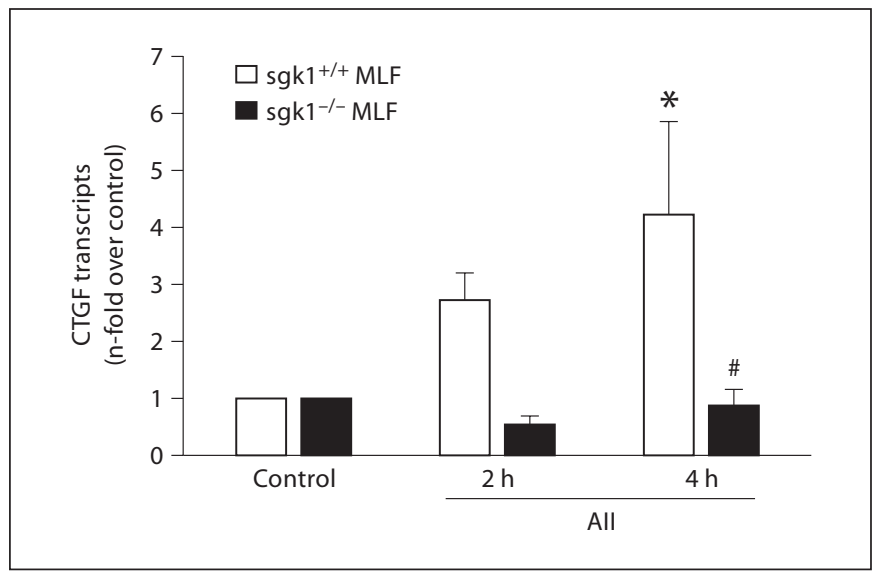

Fig. 4. Angiotensin II (AII) increases CTGF transcript levels in lung fibroblast from $s g k 1^{+/+}$but not from $s g k 1^{-/-}$mice. Arithmetic means $\pm \operatorname{SEM}(n=3)$ of CTGF transcript levels over GAPDH levels in primary mouse lung fibroblasts from mice lacking SGK1 $\left(s g k 1^{-1-}\right.$, closed bars) and their wild-type littermates $\left(s g k 1^{+/+}\right.$, open bars) prior to (control) and after 2- and 4-hour treatment with 10 nM AII. * Significant difference from control. \# Significant difference from $s g k 1^{+/+}$at the same condition.

illustrated in figure 4, basal CTGF transcript levels were not different between $s g k 1^{-/-}$and $s g k 1^{+/+}$fibroblasts. Angiotensin II, $10 \mathrm{nM}$, however, increased CTGF transcript levels in wild-type but not in $s g k 1^{-/-}$mice fibroblasts. These observations indicate that transcriptional upregulation of CTGF requires the participation of SGK1.

When CTGF protein was quantified by Western blotting the upregulation in wild-type cells by angiotensin II was indeed mirrored by an increased amount of CTGF protein in these cells. In $s g k 1^{-/-}$mouse fibroblasts, in contrast, CTGF protein levels were not significantly increased by angiotensin II (fig. 5). These results strongly indicate that the stimulation of CTGF protein expression by angiotensin II depends on the presence of SGK1.

\section{Discussion}

The present observations demonstrate that the serumand glucocorticoid-inducible kinase SGK1 is a transcriptional target of angiotensin II. Thus, angiotensin II upregulates SGK1 expression not only by increasing aldosterone release and subsequent mineralocorticoid stimulation of SGK1 transcription [33, 34], but as well by a more direct stimulation of SGK1 transcription.

SGK1-Dependent Upregulation of CTGF by Angiotensin II
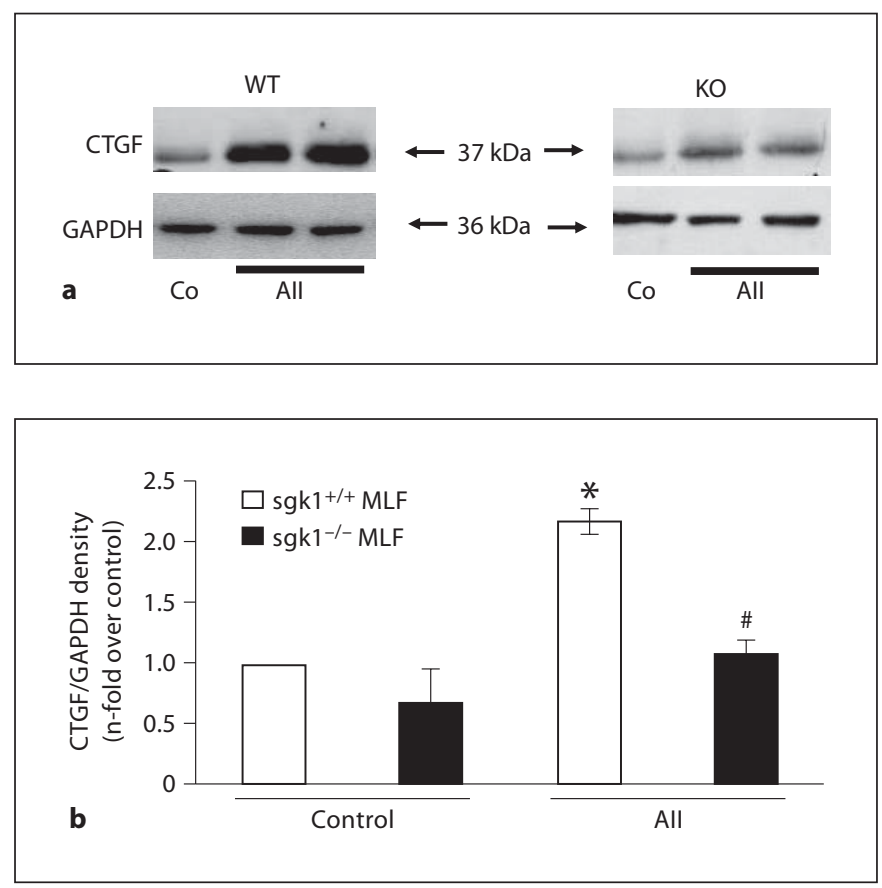

Fig. 5. Angiotensin II (AII) increases CTGF protein expression in fibroblasts from $s g k 1^{+/+}$but not from $s g k 1^{-/-}$mice. a Representative Western blots demonstrating CTGF and GAPDH protein levels in primary mouse lung fibroblasts from mice lacking SGK1 $\left(\mathrm{sgk1}^{-{ }^{-}}, \mathrm{KO}\right.$, right panel) and their wild-type littermates ( $\mathrm{sgk1} 1^{+/+}$, WT, left panel) prior to (Co) and after 4-hour treatment with $10 \mathrm{nM}$ AII. b Arithmetic means \pm SEM $(\mathrm{n}=4)$ of CTGF over GAPDH protein abundance in fibroblasts from $\mathrm{sgk1}^{-/-}$(closed bars) and $\mathrm{sgk1}^{+/+}$(open bars) mice prior to (control) and after 4hour treatment with $10 \mathrm{nM}$ AII. * Significant difference from the respective untreated cells. " Significant difference between sgk $1^{+/+}$ and $\mathrm{sgk} 1^{-1-}$ mice in the presence of AII.

The present observations further reveal the participation of SGK1 in the signaling mediating the stimulating effect of angiotensin II on the transcription and protein expression of CTGF [15, 18-27]. CTGF, a member of the CCN (ctgf/cyr61/nov) gene family [47], is a key mediator of matrix protein formation $[48,49]$. Loss of function mutations of CTGF are lethal partly due to major skeletal defects as a result of impaired matrix remodeling [50]. CTGF is upregulated in several fibrotic diseases such as scleroderma [51], cardiac fibrosis [26, 27], hepatic fibrosis [52] and diabetic nephropathy [53]. CTGF has been demonstrated to upregulate several profibrotic factors such as collagen, integrin $\alpha 5$ and fibronectin [54]. SGK1-dependent upregulation of CTGF may participate in those fibrosing diseases where excessive SGK1 transcription has

Kidney Blood Press Res 2008;31;80-86 
been observed, such as diabetic nephropathy [35-37], glomerulonephritis [38], cardiac fibrosis [39], lung fibrosis [40], liver cirrhosis [41], Crohn's disease [42] and fibrosing pancreatitis [43].

To the extent that SGK1 is upregulated by mineralocorticoids, it could similarly participate in the stimulation of fibrosis by mineralocorticoid excess, which, for instance, has been shown to induce cardiac fibrosis [55, 56 in a pressure-independent manner via cardiac mineralocorticoid receptors $[57,58]$. Inhibition of those receptors would abrogate the aldosterone-induced fibrosis but favor increase of angiotensin II release and thus promote angiotensin II-induced fibrosis. SGK1 has indeed been shown to participate in the stimulation of cardiac CTGF formation during mineralocorticoid excess [39]. Moreover, SGK1 has been shown to potentiate the stimulating effect of hyperglycemia on matrix protein formation [35].

Mechanisms linking SGK1 with CTGF expression could at least in theory involve nuclear factor NFKB [31]. SGK1 associates with and activates IкB kinase $\beta$ (IKK $\beta$ ), which in turn phosphorylates $I \kappa \mathrm{B} \alpha$, leading to degrada-

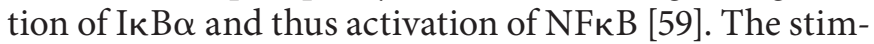
ulating effect of the mineralocorticoid DOCA on cardiac CTGF indeed requires both, SGK1 and NFкB [39]. Angiotensin II similarly signals through NFKB [60-62], but may not require NFKB for stimulation of fibrosis [63]. SGK1 further phosphorylates glycogen synthase kinase $3 \beta$, an effect, however, apparently not critical for cardiac fibrosis [64]. Moreover, SGK1 may be effective through its well-known role in the regulation of channels and transporters [31, 65-67]. In any case, additional experimentation will be necessary to elucidate whether the SGK1-dependent pathway stimulated by angiotensin II involves more than NFKB.

\section{Acknowledgments}

The authors are indebted to L. Subasic for meticulous preparation of the manuscript. They gratefully acknowledge the support of the Deutsche Forschungsgemeinschaft (GRK13024).

\section{References}

-1 Brown RD, Ambler SK, Mitchell MD, Long CS: The cardiac fibroblast: therapeutic target in myocardial remodeling and failure. Annu Rev Pharmacol Toxicol 2005;45:657-687.

-2 Opie LH, Sack MN: Enhanced angiotensin II activity in heart failure: reevaluation of the counterregulatory hypothesis of receptor subtypes. Circ Res 2001;88:654-658.

- 3 Candido R, Jandeleit-Dahm KA, Cao Z, Nesteroff SP, Burns WC, Twigg SM, Dilley RJ, Cooper ME, Allen TJ: Prevention of accelerated atherosclerosis by angiotensinconverting enzyme inhibition in diabetic apolipoprotein E-deficient mice. Circulation 2002;106:246-253.

-4 Rasoul S, Carretero OA, Peng H, Cavasin MA, Zhuo J, Sanchez-Mendoza A, Brigstock DR, Rhaleb NE: Antifibrotic effect of AcSDKP and angiotensin-converting enzyme inhibition in hypertension. J Hypertens 2004;22:593-603.

5 Struthers AD, MacDonald TM: Review of aldosterone- and angiotensin II-induced target organ damage and prevention. Cardiovasc Res 2004;61:663-670.

6 Touyz RM: Molecular and cellular mechanisms in vascular injury in hypertension: role of angiotensin II. Curr Opin Nephrol Hypertens 2005; 14:125-131.

7 Brown NJ, Vaughan DE, Fogo AB: The renin-angiotensin-aldosterone system and fibrinolysis in progressive renal disease. Semin Nephrol 2002;22:399-406.
8 Connolly SB, Sadlier D, Kieran NE, Doran P, Brady HR: Transcriptome profiling and the pathogenesis of diabetic complications. J Am Soc Nephrol 2003;14:S279-S283.

-9 Gross O, Schulze-Lohoff E, Koepke ML, Beirowski B, Addicks K, Bloch W, Smyth N, Weber M: Antifibrotic, nephroprotective potential of ACE inhibitor vs. AT1 antagonist in a murine model of renal fibrosis. Nephrol Dial Transplant 2004;19:17161723 .

10 Hilgers KF, Mann JF: Role of angiotensin II in glomerular injury: lessons from experimental and clinical studies. Kidney Blood Press Res 1996;19:254-262.

11 Okada K, Okawa E, Shibahara H, Maruyama T, Maruyama N, Matsumoto K, Takahashi S: Combination therapy with angiotensin-converting enzyme inhibitor and oral adsorbent of uremic toxins can delay the appearance of glomerular sclerosis and interstitial fibrosis in established renal failure. Kidney Blood Press Res 2004;27:218-225.

12 Prieto M, Rodriguez-Pena A, Arevalo M, Rivas JV, Duwel A, Eleno N, Sanchez RJ, Morales AI, Lopez-Novoa JM, Perez-Barriocanal F: Effect of the long-term treatment with trandolapril on endoglin expression in rats with experimental renal fibrosis induced by renal mass reduction. Kidney Blood Press Res 2005;28:32-40.

13 Wolf G: Vasoactive factors and tubulointerstitial injury. Kidney Blood Press Res 1999; 22:62-70.
14 Bataller R, Brenner DA: Liver fibrosis. J Clin Invest 2005;115:209-218

-15 Kurikawa N, Suga M, Kuroda S, Yamada K, Ishikawa $\mathrm{H}$ : An angiotensin II type 1 receptor antagonist, olmesartan medoxomil, improves experimental liver fibrosis by suppression of proliferation and collagen synthesis in activated hepatic stellate cells. Br J Pharmacol 2003;139:1085-1094.

16 Nadrous HF, Ryu JH, Douglas WW, Decker PA, Olson EJ: Impact of angiotensin-converting enzyme inhibitors and statins on survival in idiopathic pulmonary fibrosis. Chest 2004;126:438-446.

17 Wilkinson-Berka JL, Fletcher EL: Angiotensin and bradykinin: targets for the treatment of vascular and neuro-glial pathology in diabetic retinopathy. Curr Pharm Des 2004;10: 3313-3330.

18 Ahmed MS, Oie E, Vinge LE, Yndestad A, Oystein AG, Andersson Y, Attramadal T, Attramadal $\mathrm{H}$ : Connective tissue growth factor - a novel mediator of angiotensin IIstimulated cardiac fibroblast activation in heart failure in rats. J Mol Cell Cardiol 2004; 36:393-404.

19 Andersen S, van Nieuwenhoven FA, Tarnow L, Rossing P, Rossing K, Wieten L, Goldschmeding R, Parving HH: Reduction of urinary connective tissue growth factor by losartan in type 1 patients with diabetic nephropathy. Kidney Int 2005;67:2325-2329. 
20 Bolick DT, Hatley ME, Srinivasan S, Hedrick CC, Nadler JL: Lisofylline, a novel anti-inflammatory compound, protects mesangial cells from hyperglycemia- and angiotensin II-mediated extracellular matrix deposition. Endocrinology 2003;144:5227-5231.

-21 Finckenberg P, Inkinen K, Ahonen J, Merasto $S$, Louhelainen M, Vapaatalo H, Muller D, Ganten D, Luft F, Mervaala E: Angiotensin II induces connective tissue growth factor gene expression via calcineurin-dependent pathways. Am J Pathol 2003;163:355-366.

22 He Z, Way KJ, Arikawa E, Chou E, Opland DM, Clermont A, Isshiki K, Ma RC, Scott JA, Schoen FJ, Feener EP, King GL: Differential regulation of angiotensin II-induced expression of connective tissue growth factor by protein kinase $\mathrm{C}$ isoforms in the myocardium. J Biol Chem 2005;280:15719-15726.

23 Huang S, Liu F, Sha Z, Fu P, Yang Y, Xu Y, Zhou H: Effect of high glucose, angiotensin II and receptor antagonist losartan on the expression of connective tissue growth factor in cultured mesangial cells. Chin Med J (Engl) 2003;116:554-557.

24 Iwanciw D, Rehm M, Porst M, GoppeltStruebe M: Induction of connective tissue growth factor by angiotensin II: integration of signaling pathways. Arterioscler Thromb Vasc Biol 2003;23:1782-1787.

25 Liu BC, Sun J, Chen Q, Ma KL, Ruan XZ, Phillips AO: Role of connective tissue growth factor in mediating hypertrophy of human proximal tubular cells induced by angiotensin II. Am J Nephrol 2003;23:429-437.

-26 Ruperez M, Lorenzo O, Blanco-Colio LM, Esteban V, Egido J, Ruiz-Ortega M: Connective tissue growth factor is a mediator of angiotensin II-induced fibrosis. Circulation 2003;108:1499-1505.

-27 Ruperez M, Ruiz-Ortega M, Esteban V, Lorenzo O, Mezzano S, Plaza JJ, Egido J: Angiotensin II increases connective tissue growth factor in the kidney. Am J Pathol 2003;163:1937-1947.

28 Lee CI, Guh JY, Chen HC, Hung WC, Yang YL, Chuang LY: Advanced glycation endproduct-induced mitogenesis and collagen production are dependent on angiotensin II and connective tissue growth factor in NRK49F cells. J Cell Biochem 2005;95:281-292.

29 Lang F, Cohen P: Regulation and physiological roles of serum- and glucocorticoid-induced protein kinase isoforms. Sci STKE 2001;2001:RE17.

- 30 Firestone GL, Giampaolo JR, O’Keeffe BA: Stimulus-dependent regulation of the serum- and glucocorticoid-inducible protein kinase (Sgk) transcription, subcellular localization and enzymatic activity. Cell Physiol Biochem 2003;13:1-12.

- 31 Lang F, Bohmer C, Palmada M, Seebohm G, Strutz-Seebohm N, Vallon V: (Patho)physiological significance of the serum- and glucocorticoid-inducible kinase isoforms. Physiol Rev 2006;86:1151-1178.
32 Simon P, Schneck M, Hochstetter T, Koutsouki E, Mittelbronn M, Merseburger A, Weigert C, Niess A, Lang F: Differential regulation of serum- and glucocorticoid-inducible kinase 1 (SGK1) splice variants based on alternative initiation of transcription. Cell Physiol Biochem 2007;20:715-728.

33 Pearce D: SGK1 regulation of epithelial sodium transport. Cell Physiol Biochem 2003; 13:13-20.

-34 Verrey F, Loffing J, Zecevic M, Heitzmann D, Staub O: SGK1: aldosterone-induced relay of $\mathrm{Na}^{+}$transport regulation in distal kidney nephron cells. Cell Physiol Biochem 2003;13: 21-28.

35 Feng Y, Wang Q, Wang Y, Yard B, Lang F: SGK1-mediated fibronectin formation in diabetic nephropathy. Cell Physiol Biochem 2005;16:237-244.

36 Kumar JM, Brooks DP, Olson BA, Laping NJ: $\mathrm{Sgk}$, a putative serine/threonine kinase, is differentially expressed in the kidney of diabetic mice and humans. J Am Soc Nephrol 1999;10:2488-2494.

- 37 Lang F, Klingel K, Wagner CA, Stegen C, Warntges S, Friedrich B, Lanzendorfer $M$, Melzig J, Moschen I, Steuer S, Waldegger S, Sauter M, Paulmichl M, Gerke V, Risler T, Gamba G, Capasso G, Kandolf R, Hebert SC, Massry SG, Broer S: Deranged transcriptional regulation of cell-volume-sensitive kinase hSGK in diabetic nephropathy. Proc Natl Acad Sci USA 2000;97:8157-8162.

- 38 Friedrich B, Warntges S, Klingel K, Sauter M, Kandolf R, Risler T, Muller GA, Witzgall R, Kriz W, Grone HJ, Lang F: Up-regulation of the human serum and glucocorticoid-dependent kinase-1 in glomerulonephritis. Kidney Blood Press Res 2002;25:303-307.

39 Vallon V, Wyatt AW, Klingel K, Huang DY, Hussain A, Berchtold S, Friedrich B, Grahammer F, Belaiba RS, Gorlach A, Wulff P, Daut J, Dalton ND, Ross J Jr, Flogel U, Schrader J, Osswald H, Kandolf R, Kuhl D, Lang F: SGK1-dependent cardiac CTGF formation and fibrosis following DOCA treatment. J Mol Med 2006;84:396-404.

40 Wärntges S, Klingel K, Weigert C, Fillon S, Buck M, Schleicher E, Rodemann HP, Knabbe C, Kandolf R, Lang F: Excessive transcription of the human serum and glucocorticoid-dependent kinase hSGK1 in lung fibrosis. Cell Physiol Biochem 2002;12:135142.

41 Fillon S, Klingel K, Warntges S, Sauter M, Gabrysch S, Pestel S, Tanneur V, Waldegger S, Zipfel A, Viebahn R, Haussinger D, Broer S, Kandolf R, Lang F: Expression of the serine/threonine kinase hSGK1 in chronic viral hepatitis. Cell Physiol Biochem 2002;12:4754

-42 Waldegger S, Klingel K, Barth P, Sauter M, Rfer ML, Kandolf R, Lang F: h-sgk serinethreonine protein kinase gene as transcriptional target of transforming growth factor beta in human intestine. Gastroenterology 1999;116:1081-1088.
43 Klingel K, Warntges S, Bock J, Wagner CA, Sauter M, Waldegger S, Kandolf R, Lang F: Expression of cell volume-regulated kinase h-sgk in pancreatic tissue. Am J Physiol 2000;279:G998-G1002.

-44 Lam S, Verhagen NA, Strutz F, van der Pijl JW, Daha MR, van Kooten C: Glucose-induced fibronectin and collagen type III expression in renal fibroblasts can occur independent of TGF- $\beta_{1}$. Kidney Int 2003;63: 878-888.

45 Schuttert JB, Liu MH, Gliem N, Fiedler GM, Zopf S, Mayer C, Muller GA, Grunewald RW: Human renal fibroblasts derived from normal and fibrotic kidneys show differences in increase of extracellular matrix synthesis and cell proliferation upon angiotensin II exposure. Pflügers Arch 2003;446:387-393.

-46 Wulff P, Vallon V, Huang DY, Volkl H, Yu F, Richter K, Jansen M, Schlunz M, Klingel K, Loffing J, Kauselmann G, Bosl MR, Lang F, Kuhl D: Impaired renal $\mathrm{Na}^{+}$retention in the sgk1-knockout mouse. J Clin Invest 2002; 110:1263-1268.

47 Moussad EE, Brigstock DR: Connective tissue growth factor: what's in a name? Mol Genet Metab 2000;71:276-292.

48 Brigstock DR: The CCN family: a new stimulus package. J Endocrinol 2003;178:169-175.

49 Ihn H: Pathogenesis of fibrosis: role of TGF$\beta$ and CTGF. Curr Opin Rheumatol 2002; 14: 681-685.

50 Perbal B: CCN proteins: multifunctional signalling regulators. Lancet 2004;363:62-64.

-51 Leask A, Holmes A, Black CM, Abraham DJ: Connective tissue growth factor gene regulation. Requirements for its induction by transforming growth factor- $\beta_{2}$ in fibroblasts. J Biol Chem 2003;278:13008-13015.

52 Rachfal AW, Brigstock DR: Connective tissue growth factor (CTGF/CCN2) in hepatic fibrosis. Hepatol Res 2003;26:1-9.

53 Wang J, Barbry P, Maiyar AC, Rozansky DJ, Bhargava A, Leong M, Firestone GL, Pearce D: SGK integrates insulin and mineralocorticoid regulation of epithelial sodium transport. Am J Physiol Renal Physiol 2001;280: F303-F313.

54 Frazier K, Williams S, Kothapalli D, Klapper $\mathrm{H}$, Grotendorst GR: Stimulation of fibroblast cell growth, matrix production, and granulation tissue formation by connective tissue growth factor. J Invest Dermatol 1996;107: 404-411.

55 Fujisawa G, Dilley R, Fullerton MJ, Funder JW: Experimental cardiac fibrosis: differential time course of responses to mineralocorticoid-salt administration. Endocrinology 2001;142:3625-3631.

-56 Young M, Head G, Funder J: Determinants of cardiac fibrosis in experimental hypermineralocorticoid states. Am J Physiol 1995; 269:E657-E662.

57 Brilla CG, Weber KT: Reactive and reparative myocardial fibrosis in arterial hypertension in the rat. Cardiovasc Res 1992;26:671677. 
58 Young MJ, Funder JW: The renin-angiotensin-aldosterone system in experimental mineralocorticoid-salt-induced cardiac fibrosis. Am J Physiol 1996;271:E883-E888.

59 Zhang L, Cui R, Cheng X, Du J: Antiapoptotic effect of serum- and glucocorticoidinducible protein kinase is mediated by novel mechanism activating ІкB kinase. Cancer Res 2005;65:457-464.

60 Costanzo A, Moretti F, Burgio VL, Bravi C Guido F, Levrero M, Puri PL: Endothelial activation by angiotensin II through $\mathrm{NF} \kappa \mathrm{B}$ and p38 pathways: involvement of NFKB-inducible kinase (NIK), free oxygen radicals, and selective inhibition by aspirin. J Cell Physiol 2003;195:402-410.
61 Phillips MI, Kagiyama S: Angiotensin II as a pro-inflammatory mediator. Curr Opin Investig Drugs 2002;3:569-577.

62 Vaziri ND, Bai Y, Ni Z, Quiroz Y, Pandian R, Rodriguez-Iturbe B: Intra-renal angiotensin II/AT1 receptor, oxidative stress, inflammation, and progressive injury in renal mass reduction. J Pharmacol Exp Ther 2007;323: 85-93.

63 Tharaux PL, Chatziantoniou C, Fakhouri F, Dussaule JC: Angiotensin II activates collagen I gene through a mechanism involving the MAP/ER kinase pathway. Hypertension 2000;36:330-336.

64 Wyatt AW, Hussain A, Amann K, Klingel K, Kandolf R, Artunc F, Grahammer F, Huang DY, Vallon V, Kuhl D, Lang F: DOCA-induced phosphorylation of glycogen synthase kinase $3 \beta$. Cell Physiol Biochem 2006;17: 137-144.
65 Hills CE, Bland R, Bennett J, Ronco PM, Squires PE: High glucose up-regulates ENaC and SGK1 expression in HCD-cells. Cell Physiol Biochem 2006;18:337-346.

66 Sato JD, Chapline MC, Thibodeau R, Frizzell RA, Stanton BA: Regulation of human cystic fibrosis transmembrane conductance regulator (CFTR) by serum- and glucocorticoidinducible kinase (SGK1). Cell Physiol Biochem 2007;20:91-98.

67 Seebohm G, Strutz-Seebohm N, Baltaev R, Korniychuk G, Knirsch M, Engel J, Lang F: Regulation of KCNQ4 potassium channel prepulse dependence and current amplitude by SGK1 in Xenopus oocytes. Cell Physiol Biochem 2005;16:255-262. 